\title{
Insects against crimes: teaching forensic entomology to children through comic books
}

\section{Beatriz C. F. Mendes, Letícia C. Andrade, Luana M. Silva, Verônica S. Sales, Patricia J. Thyssen}

\section{Abstract}

Forensic entomology seeks to discover useful information to investigations through insects. Flies (Insecta, Diptera) play an important role in this field. This study aims to broaden the empathy for the insect and knowledge about forensic entomology through the language of an almanac made for this purpose. The almanac, which contains 20 pages, is targeted at the public of Elementary School and addresses issues such as the life cycle of flies and the usefulness of their biological information for solving crimes. It is a fun alternative to promote scientific outreach with interspersed stories and games.

\section{Key words:}

Basic education, scientific dissemination, flies

\section{Introduction}

Forensic entomology seeks, through the study of insects, to obtain information relevant to the resolution of cases in the investigative context ${ }^{1}$. Among all insects, flies (Diptera) are the most abundant and often found in corpses and contaminated food ${ }^{1,2}$. For this reason and due to the lack of knowledge about the potential usefulness of the insects in several fields of knowledge, a lack of empathy with these organisms is noticed.

Comic books are good tools for literacy, thanks to its visual language and playful characteristics ${ }^{3}$; in addition, it is possible to approach various subjects in a simplified and accessible way through them.

Thus, in this study we developed an almanac for the public of Elementary School, with comic strip and games, aiming to broaden the empathy for insects and knowledge about forensic entomology.

\section{Results and Discussion}

In the narrative, a larva tells a boy how his life cycle in nature is, what foods the flies choose to survive, and how their family members, from their "biological histories" helped to solve a crime (Fig. 1).

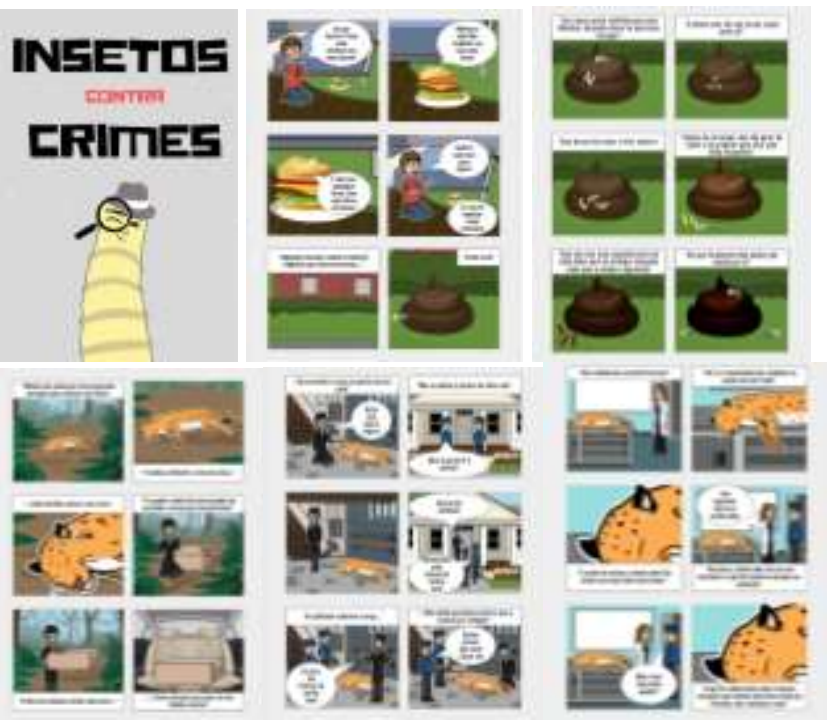

Figure 1. Cover and comics strips in the almanac.
The games played throughout history interact with the reader to make the text more attractive and also to expose some unusual themes for the child (Fig. 2).

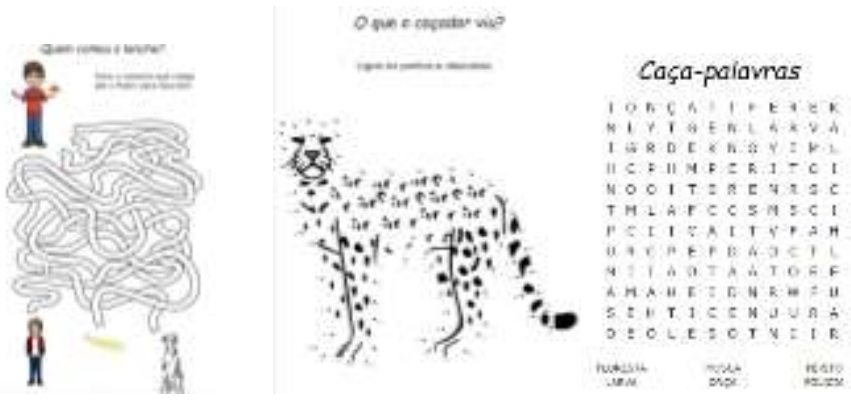

Figure 2. Games in the almanac.

\section{Conclusions}

This is a fun alternative to promote scientific outreach with interspersed stories and games. It is expected that the presentation of this content can stimulate curiosity, increasing in them the search for new knowledge and encouraging reading.

\section{Acknowledgement}

This content was the result of the final work of the discipline BZ586 Forensic Entomology, taught by the Professor PhD. Patrícia Thyssen, whom we thank for the opportunity to develop such unique skills during graduation.

\footnotetext{
1 Thyssen, P.J. Entomologia Forense. In: Entomologia Médica e Veterinária. $2^{\text {a }}$ ed. 2011, pp 229-238.

2 Carvalho, L.M.L.; Thyssen, P.J.; Linhares, A.X.; Palhares, F.A.B. Mem. Inst. Oswaldo Cruz. 2000, 95, 135-138.

${ }^{3}$ Corsini, R. Gibis na Alfabetização. Revista Educação, 2014. Avaible in: <https://www.revistaeducacao.com.br/gibis-naalfabetizacao/>
} 